\title{
The struggle for dominance in Eurasia: "The international politics of Ukrainian nationalism" by Bohdan Kordiuk in the context of geopolitical concepts of the Organisation of Ukrainian Nationalists during the 1930s
}

Zarys treści: Artykuł jest próbą przedstawienia rozwoju geopolitycznych koncepcji Organizacji Ukraińskich Nacjonalistów oraz roli, jaką w ich kształtowaniu odegrał pochodzący z 1934 r. tekst Polityka międzynarodowa ukraińskiego nacjonalizmu Bohdana Kordiuka. Źródło to publikuję w tłumaczeniu na język angielski w drugiej części tekstu. W artykule koncentruję się na omówieniu koncepcji geopolitycznych OUN w latach trzydziestych. W ograniczonym stopniu przywołuję również idee wysuwane przez organizację pod koniec lat dwudziestych, aby zilustrować różnicę, jaka zaszła po przybyciu na emigrację byłych działaczy Krajowej Egzekutywy OUN.

Outline of content: The article is an attempt to present the development of geopolitical concepts of the Organisation of Ukrainian Nationalists and the role of the 1934 text "The international politics of Ukrainian nationalism" by Bohdan Kordiuk played in shaping them. I include the source material, in an English translation, in the second part of this paper. In the article, I concentrate on the discussion of OUN's geopolitical concepts in the 1930s. To a limited extent I also mention ideas put forward by the Organisation at the end of the 1920s to illustrate the difference which occurred upon the emigration of former activists of the National Executive of OUN.

Słowa kluczowe: polityka międzynarodowa w 20-leciu międzywojennym, geopolityka, nacjonalizm ukraiński, Organizacja Ukraińskich Nacjonalistów, Bohdan Kordiuk

Keywords: international politics in the interwar period, geopolitics, Ukrainian nationalism, the Organisation of Ukrainian Nationalists, Bohdan Kordiuk 
"Two great, strong empires cannot exist in the East: it is either Ukraine or Moscovia"

Bohdan Kordiuk

The 1934 paper by Bohdan Kordiuk "The international politics of Ukrainian nationalism" appears as an important document presenting the development of the geopolitical thought in the Organisation of Ukrainian Nationalists (OUN). Along with a text from the same period written by his close companion, Ivan Gabrusevych, it seems to point to the emergence of a new, radical geopolitical vision among the younger generation OUN activists in the first half of the 1930s, in which Ukraine was to be an important geopolitical factor in Europe as well as in Asia. ${ }^{1}$ This vision reached its widest dimension in "The war doctrine of Ukrainian nationalists" by Mykhailo Kolodzinsky, completed in 1938. According to the preserved correspondence between the head of the Organisation Yevhen Konovalets and a representative of the OUN in Italy, Yevhen Onacky, this text is only the first part of the paper presented by Kordiuk during the OUN Conference in Geneva in May 1934. ${ }^{2}$ The document is stored in the Central State Archives of Supreme Bodies of Power and Government of Ukraine in Kiev. ${ }^{3}$

Bohdan Kordiuk (pseudonyms: Dik, Snip, Novy, Arkas) was born on 17 January 1908 in Lviv. In his youth he was a member of the Higher Class of Ukrainian Gymnasiums, and later one of the members of the Union of Ukrainian Nationalist Youth. ${ }^{4}$ After the founding of the Homeland Executive of the OUN, Kordiuk became the Deputy of Ivan Gabrusevych, who at the time was the leader of the sub-unit of the OUN youth organisation. ${ }^{5}$ In September 1930 Kordiuk was arrested in connection with the attack on a postal car near Bóbrka, and spent a year and a half in prison. ${ }^{6}$ Soon after leaving prison, in May 1932, he became the head of the Homeland Executive of the OUN (while Stepan Bandera became his deputy). ${ }^{7}$ As the head of the HE OUN, he made the decision to carry out the famous attack on the post office in Horodok on 30 November 1932. The action ended in failure;

1 [I. Габрусевич], Україна і Англія, Central State Archives of Higher Authorities and Government of Ukraine (hereafter: ЦДАВОВ), f. 3833, op. 3, s. 1, 1. 49; Лист Габрусевича на маргінесі рапортів Є. Ляховича, f. 3833, ор. 3, s. 1, 11. 54-55.

2 “Лист Є. Коновальця до Є. Онацького від 17 травня 1934 p.”, in: $€$. Онацький, У вічному місті IV. Записьки украӥнського журналіста 1934 рік, Торонто, 1989, p. 166.

${ }^{3}$ Новий [Б. Кордюк], Міжнародня політика україгського націонпалізму, ЦДАВОВ, f. 4363, op. 1, s. 14, 11. 1-6.

4 П. Мірчук, Нарис історії Оргвнізації Українських Націоналістів, Мюнхен, Лондон ап Нью Йорк, 1968, pр. 56-57; 3. Книш, При джерелах українського організованого націоналізму, Торонто, 1970, р. 70.

${ }_{5}^{5}$ Мірчук, Нарис історіï, p. 141.

6 Ibid., p. 151, 273; В. Янів, “Зустрічі з полк. Євгеном Коновальцем на тлі настроїв доби”, in: Євген Коновалець та його доба, Мюнхен, 1974, р. 457.

7 Мірчук, Нарис історіï, pp. 301-302. 
several members of the OUN were injured, Yuri Berezinsky and Volodymyr Staryk were killed on the spot, while Vasyl Bilas and Dmytro Danylyshyn were captured by the police and sentenced to death. As a result, the OUN organisational court agreed to the suggestion of the Organisation's president, Yevhen Konovalets, and removed Kordiuk from the post of the head of the HE OUN (his place was taken by Bandera), accusing him of insufficiently preparing the action. This decision was decisively confirmed during the Berlin Conference of the PUN and HE OUN in June $1933 .{ }^{8}$ At the same time, Kordiuk remained in the Organisation, emigrating to Berlin in January 1933. Together with Ivan Gabrusevych, Kordiuk worked for the National Press Service in the German capital, which served as a press office of the Ukrainian nationalists. According to Lev Rebet (head of the HE OUN in 1935-1939), the role played by both activists in the emigration was "subordinate". ${ }^{9}$ His time in emigration did not alleviate his radicalism, characteristic for the younger generation of OUN activists. A manifestation of this was the article, written by Kordiuk in the first half of 1934, Sobornitstvo ${ }^{10}$ of Ukrainian Nationalism, in which he argued that either Ukraine would reach the border from the Vistula in the west to the Volga in the east, or it would not be created at all.11

Kordiuk's paper dedicated to international politics comes from the same period. He presented it at the OUN Conference which took place around 6 May 1934 in Geneva. According to a letter from Yevhen Konovalets to the commander of the political unit of the Provid of the Ukrainian Nationalists, Dmytro Andriievsky, among those attending the conference were the leader of the Organisation Yevhen Konovalets, Dmytro Andriievsky, the press and propaganda referent and Secretary to the PUN Volodymyr Martynets, organisational referent of the PUN Mykola Stsiborsky, as well as OUN activists from Czechoslovakia (Yaroslav Baranovsky), Germany (Richard Jary and Ivan Gabrusevych or Kordiuk), Great Britain (Yevhen Lakhovych) and Italy (Mykhailo Turchmanovych). The reasons why Konovalets called the conference were as follows: the increasing discrepancies between the older and younger generations in the OUN, the necessity of establishing the directions of the Organisation's foreign policy, and the Organisation's activities regarding Ukrainian lands in the USSR. ${ }^{12}$ Konovalets's correspondence suggests that, apart from him, Gabrusevych, Kordiuk, Baranovsky, Turchmanovych and Andriievsky

8 Although Kordiuk was rehabilitated, in the end the leadership of the HE OUN was taken over by Bandera; Янів, Зустрічі з полк, р. 463; Мірчук, Нарис історіi, pp. 322-323.

9 Л. Ребет, Світла і тіні ОУН, Мюнхен, 1964, р. 77.

10 An untranslatable term relating to activities in all possible areas of life and/or throughout the whole territory, to which the Ukrainian national movement raised a claim. Related words: sobornist', soborny mean "unity", "unified".

11 “Лист Є. Коновальця до Д. Андрієвського від 4 червня 1934 р.”, in: Документи і матеріали з історії Організації Українських Націоналістів, vol. 2, part 2, еd. Ю. Черченко, Київ, 2007, p. 431.

12 “Лист Є. Коновальця до Д. Андрієвського від 28 квітня 1934 р.”, in: Документи і матеріали, vol. 2, part 2, Київ, 2007, p. 425. 
participated in the conference. ${ }^{13}$ The text of the first part of Kordiuk's paper was received by Onatsky, and most likely also by Martynets. ${ }^{14}$ All of this confirmed the role Kordiuk's text played in shaping the Organisation's political agenda. Kordiuk's geopolitical sketches were also well known among the wider circles of OUN activists. This is evidenced in the memories of Stepan Lenkavsky, who among illegal duplicating machine publications distributed by OUN activists mentions Stepan Okhrymovych's sketch on the principles of Ukrainian nationalism, the first part of The War Doctrine of Ukrainian Nationalists by M. Kolodzinsky, his pamphlet devoted to the January Uprising, ${ }^{15}$ his own article on the ideology of Dmytro Dontsov, ${ }^{16}$ and the geopolitical sketches of Bohdan Kordiuk. ${ }^{17}$

The starting point for Kordiuk's reflections in the text "The international politics of Ukrainian nationalism" was a statement that "until now Ukrainian nationalism has had no systematic international policy, not only due to the lack of adequate resources, but also the absence of its own international concept" ${ }^{18} \mathrm{Critical}$ attitude towards the earlier activities of the organisation in this sphere of action of the OUN was derived from the fact that it was not defined and implemented in accordance with the principles of Ukrainian nationalism. Kordiuk demonstrated his dogmatism by persuading others that "international policy is not a separate domain, it is only our worldview applied to international life". ${ }^{19}$ This assessment was confirmed by his rejection of the First Congress of Ukrainian Nationalists' decision that the OUN should be a partyless organisation, and his claim that nationalists should not seek "agreement among different national groups to create a certain front", instead, they should fight all other parties by creating "their own world". ${ }^{20}$ Paradoxically, the postulate of separation from other political groups was accompanied by the conviction that the OUN represented the interests of the entire Ukrainian nation. Paradoxically - because, according to this interpretation, all groups that did not share a nationalist worldview were de facto placed outside of the national community. These rules also referred to foreign policy - Kordiuk

13 “Лист Є. Коновальця до Є. Онацького від 17 травня 1934 p.”, in: Є. Онацький, У вічному місті IV. Записьки українського журналіста 1934 рік, Торонто, 1989, р. 165; “Лист Д. Андрієвського до Є. Коновальця від 17 травня 1934 p.”, in: Документи і матеріали, vol. 2, part 2, ed. Ю. Черченко, Київ, 2007, pp. 427-429.

14 This could be indicated by the fact the document was preserved in the archive of the Rozbudova Natsii, whose editor-in-chief was Martynets.

15 Cf. М. Буджак [М. Колодзінський], Польське повстання 1863 р., Львів, 1929.

16 Cf. С. Ленкавський, “Філософічні підстави “Націоналізму” Донцова”, Розбудова нації, 1928, no. $7-8$, pp. $272-275$.

17 С. Ленкавський, “Націоналістичний рух на ЗУЗ та 1-ий Конгрес Українських націоналістів”, in: Євген Коновалець та його доба, р. 403.

18 Новий [Богдан Кордюк], Міжнародня політика україгського націонпалізму, ЦДАВОВ, f. 4363 , op. 1 , s. $14,1.1$.

19 Ibid.

20 Ibid. 
stated that "our foreign policy is not all-Ukrainian, but exclusively ours, nationalist, which is the only Ukrainian one". ${ }^{21}$ Such nationalist policy was to have a subjective character both internally and externally. The consolidation of the position of the OUN in the country ${ }^{22}$ was to strengthen the importance of the organisation on the international scene, and vice versa.

For Kordiuk, the key element of international politics was having "a powerful geopolitical concept" which would emanate from nationalist ideology. The young activist stated that his contemporaries did not propose such concepts; instead, he found imperial ambitions in the past in the activities of Vladimir the Great and Bohdan Khmelnytsky. According to Kordiuk, the postulate of achieving a state from "the San to the Caucasus" did not exhaust Ukraine's geopolitical objectives. The activist suggested finding the "right" directions in the national tradition, and setting a grand goal for Ukraine, which would not lose validity even after gaining independence. Substantiating the problems facing Ukraine, he mentioned: the destruction of Bolshevism, the breakup of Russia, and as a result liberating the peoples of Eastern Europe and Asia. The final destruction of the Steppe (Kordiuk probably believed that Russia was its last incarnation) also created prospects for the expansion of Catholicism in the East, and the economic development of the region (i.a. a link between the Baltic and the Black Sea). The above "problems" were theses for discussion, which was supposed to take place in the nationalist spirit, because, as Kordiuk stated, "putting forward half-formed concepts harms us". At the same time, criticising the Tri-Ruthenian Alliance plan promoted by hetman Pavlo Skoropadskyi circles, or the orientation to Poland, postulated by the Ukrainian People's Republic group, Kordiuk wrote that opponents of the nationalists had, in contrast to them, produced concepts (though erroneous). For Kordiuk, the "lack of orientation" raised by the OUN meant a constantly changing direction, which he also deemed negative. Stating that the political constellations were quite solid, he explicitly suggested choosing a specific vector in foreign policy, both in the east and in the west. ${ }^{23}$

The point of departure for the deliberations on Ukraine's eastern strategy was the conviction of Russia's artificial nature and its far-reaching national diversity. Kordiuk divided the territory of the tsarist and later Soviet empire into a number of separate regions: Ukraine, Idel-Ural, Siberia, Yakutia, Green Ukraine, ${ }^{24}$ Moscovia $^{25}$

21 Ibid.

${ }^{22}$ In OUN terminology, this term was used to describe South-East territories of the Second Polish Republic, inhabited by Ukrainians.

${ }^{23}$ Новий [Богдан Кордюк], Міжнародня політика україгського націонпалізму, ЦДАВОВ, f. 4363 , op. 1 , s. $14,1.3$.

24 The Ukrainian name of the historical land, inhabited to a large extent by Ukrainians, in the South of Russian Far East (Amur and sea oblasts).

25 A popular term in Ukrainian culture used to describe the ethnic territory Great Russians (Moskals), approximately matching the boundaries of the Grand Duchy of Moscow in the mid16th century (before annexing the khanates: Kazan and Astrakhan oblasts). 
and Greater Finland (from the Gulf of Bothnia to the Urals). At the same time, Kordiuk believed that since the Crimean War Russia had been in a state of collapse, only temporarily halted by the Bolsheviks. By synthesising these convictions, the OUN activist brought forward a proposal for the liberation of "enslaved nations" by Ukraine. The politics towards smaller nations of Eastern Europe and Asia postulated by Kordiuk was ambiguous. On the one hand, he argued that "small nations will be used not only as a decentralisation material against Moscow, but we will also build our messianism and imperialism on that basis". ${ }^{26}$ On the other, however, the OUN activist advocated the creation of a new form of imperialism based on the idea of freedom and national rule. It is impossible to avoid the question of what would have happened if the freedom of a certain nation had been at odds with the demands of the Ukrainian state.

In the west, Kordiuk proposed solving Central Europe affairs with a "triumvirate" of Italy-United Germany-United Ukraine. According to this vision, between the three powers there would be a number of countries built on the basis of the national principle. Kordiuk stated, slightly ominously, that this whole "complex of nations would be in the claws, but also under the care of the three states". ${ }^{27}$ Germany, Italy and Ukraine were, in his view, predestined to play such a role as "among these nations a new worldview emerges, and they are the chorus leaders of the new world order" ${ }^{28}$ Kordiuk expressed his ideological inspiration in the form of Nazism and Fascism by calling Ukrainian nationalists "co-creators of the new world order", and the Ukrainian people - "the master race" (in the text Herrenvolk). ${ }^{29}$

These theses of Kordiuk's met with criticism from one of the most committed foreign policy activists in the OUN, Yevhen Onatsky. In a letter to Konovalets, the activist claimed that an alliance between Italy and United Germany was impossible, given that Rome was doing everything to prevent Germany's unification. According to Onatsky, the realisation of this perspective would undercut the prospects of Italian expansion in the Balkans and create a state of constant threat at the northern borders of the country. The OUN representative in Italy also posed a key question: "Is United Germany in the interests of United Ukraine?". And he replied: "I believe it is not. Because United Germany, with 80 million aggressive Germans, would be a constant threat also for Ukraine, as the Germans in their 'geopolitical' concept regard Ukraine as one of its territories". ${ }^{30}$ Quoting fragments of Adolf Hitler's Mein Kampf, Onatsky portrayed the contradictions of Kordiuk's visions and hopes with the real plans (and, as it later turned out, also directions) of Nazi Germany's politics. The head of the OUN in Italy also drew attention to

26 Ibid., 1. 5.

27 Ibid.

28 Ibid.

29 Ibid., 1. 6.

30 “Лист Є. Онацького до Є. Коновальця від 20 травня 1934 p.", in: Онацький, У вічному місті IV, pp. $172-173$. 
the differing vectors of Rome and Berlin's politics towards Japan and its possible conflict with the USSR, which additionally complicated the implementation of the demands put forward by Kordiuk. Onatsky stated:

As we can see, the matter is not as simple as the author of the paper believes. Sitting behind a desk, you can build as many "triangles" as you like - you just need to emphasise one side of the matter and close your eyes to all the others. The "geopolitical concept" is as good as any other concept, as it helps, according to the author "to collect all the existing problems which concern the interests of the Ukrainian nation, and consider them from my own point of view" $[\ldots]$

But yet!

There can be no dogma here. Politics in general, and foreign policy in particular, is an art in which one with the necessary skills, talent and abilities, without which fumblers spoil the best concepts with no attention to any "triangles", can produce masterpieces that the world will admire. ${ }^{31}$

Analysing the international situation, Onatsky - incidentally, a decent politi$\operatorname{cian}^{32}$ - stated that Kordiuk's claim about the relative constancy of political constellations completely misrepresented reality. According to the OUN representative in Italy, the situation sometimes changed from day to day, requiring international participants to be "incredibly flexible", able to capture favourable moments in the fluid changeability of circumstances, and able to explore their further development in one way or another". ${ }^{33}$ Onatsky stated that for those unable to grasp the "colossal game of events and situations" it may be convenient to close themselves within a single concept. These words were a clear allusion to Kordiuk himself, and perhaps also to the whole younger generation of Ukrainian nationalists in general (whose actions Onatsky often criticised). ${ }^{34}$

It is unclear whether these common-sense assessments of OUN representative in Italy were passed on to Kordiuk himself. Even if they were, they did not soften the dogmatism and radicalism presented by the young member of the OUN. After Yevhen Konovalets's death, in the face of rising opposition from young activists against PUN and the head of the organisation Andriy Melnyk, Kordiuk voiced his support of the opposition faction. The young activist of the organisation Yaroslav Haivas recalled a meeting with Kordiuk, which occurred in August 1939 in Vienna, in the following way:

${ }^{31}$ Ibid., p. 173.

32 Cf. A.A. Zięba, Lobbing dla Ukrainy w Europie Międzywojennej. Ukraińskie Biuro Prasowe w Londynie i jego konkurenci polityczni (do roku 1932), Kraków, 2010, pp. 110-111.

33 “Лист Є. Онацького до Є. Коновальця від 20 травня 1934 p.”, in: Онацький, У вічному місті IV, p. 174.

34 An example of this can be e.g. Onatsky's severe criticism regarding the attack on the headmaster of a Lviv academic gymnasium, Ivan Babiy, carried out by the HE OUN; cf. "Лист Є. Онацького до В. Мартинця від 7 серпня 1934”, in: Онацький, У вічному місті IV, pp. 263-265. 
"Do not be surprised when he starts attacking people closer and closer to him, and at the end - the deceased Colonel Konovalets", [Yevhen] Vretsiona warned me, perhaps to reduce the weight of Kordiuk's charges. And that is what happened. And I, completely thrown and unaware of the emigrant lobby, listened in silence. The one who Kordiuk called "the president" got it the worst. Who is that "president", I thought, but I felt stupid to ask. It was only later that I realised that the "president" was Yaroslav Baranovsky, as he was the president of CESUS. ${ }^{35}$

Haivas also characterised Kordiuk as a supporter of "building the state from the first village" by Mykhailo Kolodzinsky. This information is important, as it provides direct evidence of the positive reception of the part of The War Doctrine of Ukrainian Nationalists in which Kolodzinsky presented his idea for a nationalist uprising combined with ethnic cleansing on Poles and Jews, at least among younger generations of OUN activists. ${ }^{36}$ Kordiuk's radicalism likely mellowed in subsequent years. He spent most of the World War II period (from 1941) in a German prison. After the end of the conflict, he joined a faction opposing Stepan Bandera, OUN Abroad (OUN-A), which most seriously considered the postulate of the program's democratisation. He died in February 1988 in Munich, after a long illness. ${ }^{37}$

Bohdan Kordiuk's geopolitical reflections did not contradict what he himself believed to be a novum in the OUN thought. Already in 1928, i.e. one year before the Organisation was founded, a PUN member Dmytro Andriievsky published a two-part article in the official OUN journal Rozbudova Natsii ("Development of the Nation"), entitled "Ukraine in global politics". The ideological speaker Andriievsky, probably inspired by the fashionable pan-European projects of Richard von Coudenhove-Kalergi and Aristide Briand, prophesied a conflict between the united Europe and Asia; Ukraine was to tip the balance, as an inseparable part of European civilization whose "independence would weaken Euarasia, and shift the latter's borders eastward: from the Carpathians to the Caucasus and the Caspian Sea". ${ }^{38}$ Between Europe and Russia there would be "a strong wall of the Great Nation". ${ }^{39}$ While this, still modestly outlined, vision of Ukraine as a decisive force in shaping Eastern Europe was adopted in the OUN, the pan-European thread was rejected (as unfavourable to revisionism), and raising it by Andriievsky caused him

35 Я. Гайвас, Воля изіни не має, Торонто, 1971, pp. 147-148.

${ }^{36}$ Haivas also recalled that at that time OUN activists in Vienna "hotly debated" the concept. The activist also referred to his conversation with Yaroslav Baranovsky, which suggested that the OUN was not able to organise an uprising at that time; ibid., pp. 156, 265. This information suggests we should approach assessments appearing in Ukrainian historiography, stating that this work was "little known (or unknown altogether) among most members of the OUN", with scepticism; cf. В. В’ятрович, Друга польсько-українська війна 1942-1947, Київ, 2012, р. 52.

37 R. Wysocki, Organizacja Ukraińskich Nacjonalistów w Polsce w latach 1929-1939. Geneza, struktura, program, ideologia, Lublin, 2003, p. 411.

38 Д. Андрієвський, “Україна в світовій політиці”, Розбудова націï, 1928, no. 10-11, p. 381; Zięba, Lobbing dla Ukrainy, p. 349.

39 Андрієвський, Україна в світовій, р. 381. 
to abandon the preparation of a paper on foreign policy during the Congress of Ukrainian Nationalists (held in Vienna between 27 January and 3 February 1929). ${ }^{40}$

The paper was eventually developed by Zenon Pelensky. In his theses, he argued that Ukraine should conduct its foreign policy in three separate geopolitical spheres: Galician-Balkan, Belarusian-Baltic and Caspian-Caucasian. In the first of these, Ukrainians were supposed to strive to establish close relations with states hostile towards Poland and the countries of the Little Entente. The support of Bulgaria and Hungary was also to aid establishing close relations with Germany and Italy. According to Pelensky, this policy was supposed to allow Ukraine to master the Black Sea straits, and consequently enable it to join the world's major powers. In the Belarusian-Baltic space, the OUN activist advocated using Belarus, Lithuania and the other Baltic states. He elaborated, "it is generally about the politics of two arms, that is - the southern arm, which goes through Bulgaria and Hungary to Germany and Italy, and the northern arm, which goes through Belarus and Lithuania to Germany again". ${ }^{41}$ As Pelensky considered Poland, rather than the Soviet Union, as the main enemy of Ukraine, the Caspian-Caucasian space was less important to him. Recognising the necessity of mastering natural resources on the territory as the basis of Ukrainian politics (and thus cutting Russia off), Pelensky postulated establishing close relations with Georgia, Armenia, Azerbaijan, as well as the Don and Kuban Cossacks, and the Tatars of the Volga, who together were to create "a European Cossack federation". This whole concept was oriented towards cooperation with the revisionist camp, and destroying the "French system in Europe". Pelensky's reflections clearly show a departure from the idea of a struggle driven by the superpower Ukraine of pan-Europe with Russian Asia, in favour of a force seeking to overthrow the Versailles order. ${ }^{42}$ Although Pelensky soon left the organisation and joined UNDO, this core idea of his paper remained in force in the OUN throughout the interwar period.

Geopolitical concepts at the onset of OUN were discussed primarily among emigrant activists. But not exclusively. The first years of the organisation's history also include the text "Ukrainian imperialism", written by an activist of the OUN

40 “Інформаційна записька Д. Андрієвського про стан підготовки рефератів для I конгресу ОУН 'Уваги' щодо підготовки конгресу українських націоналістів”, in: Документи i матеріали з історії Організації Українських Націоналістів, vol. 1: 1927-1930, eds. Ю. Черченко, О. Кучерук, Київ, 2005, p. 91; A critical reception of pan-European ideas in the OUN is also suggested by the articles of OUN judge Makar Kushnir and Yevhen Onatsky in the nationalist journal Ukrayinskyi holos; cf. В. Богуш [М. Кушнір], "Паневропа за проектом Бряна”, Украйнський Голос, 1930, по. 28, pp. 1-2; Є. Онацький, “Паневропа чи антиевропа”, Український Голос, 1930, nо. 20-22.

41 3. Пеленський, “Міжнародня політика України [Друге півріччя 1928 - початок 1929] Тези реферату про зовнішню політику України, виготовлений для Конгресу Українських Націоналістів в січні 1929 р.”, in: Коньрес Українських Націоналістів 1929 р.: Документи і матеріали, еd. В. Муравський, Львів, 2006, р. 270.

${ }^{42}$ Ibid., p. 271-273. 
under the pseudonym Murovych..$^{43}$ A two-page document from 1932 of the same title, signed with initials M. K., a police copy of an OUN brochure, can be found in the State Archives of the Lviv Oblast. ${ }^{44}$ The text presented a vision in which the above-mentioned concepts of Pelensky and Andriievsky could be considered realistic, and even minimalist. Its author argued:

Our [Ukrainian] flag will be flying in Erzurum, and somewhere far in the east our armoured ships will defend our port in Vladivostok. We will be the ones to carry true European culture into the Far East with weapons in hand, as once the Crusaders spread the Christian faith with fire and sword. This is no fantasy! Let us remember that there are countless Ukrainian colonies throughout Turkestan and Siberia, and the vast space of the Green Ukraine is our ethnographic territory. In the west we will draw our borders along the Vistula, in the south - the Danube, because we do not only want to be free in our ethnographic territory. We want to be strong and full of glory. We want to be an empire that shakes the Eurasian continent. ${ }^{45}$

The author of "Ukrainian imperialism" introduced previously unknown proposals into the debate on the geopolitical mission of Ukraine. While Pelensky and Andriievsky instead postulated shifting the borders of Russia to the east and north, the author of the above text went much further. By emphasising the presence of the Ukrainian colonies in Central Asia and the Far East, he came close to suggesting a breakup of the empire and limiting Russia to the borders of the Grand Duchy of Moscow from 1552. His successors took up this thought, while occasionally mitigating the expression of the above completely unrealistic vision.

The theme of the breakup of Russia is already clearly present in Kordiuk's The International Politics of Ukrainian Nationalism. It also appears in the 1934 text by Ivan Gabrusevych Ukraine and England. The document was a proposal of a young nationalist regarding the directions of propaganda in the UK. According to Gabrusevych, the European triangle Germany-Italy-Ukraine was to be complemented by the Asian triangle England-Japan-Ukraine. Demanding the destruction of the Comintern and breakup of Russia, the OUN activist called for the liberation, and then subjugation under Ukrainian influence, of the peoples of the Caucasus, Idel-Ural and Turkestan. This action was motivated not only by the necessity of limiting Russia to the northern territories and finally ending the pressure on the English estates in Asia; the OUN activist was also convinced that the establishment of such a "triumvirate" would entail the establishment of a trade route running from the Baltic Sea through the Niemen or Daugava, and further the Dnieper,

43 “Реферат ОУН на ЗУЗ (1928-1932)", in: Документи і матеріали з історії Організації Українських Націоналістів, vol. 2, part 1, ed. Ю. Черченко, Київ, 2010, р. 272.

44 The initials "M. K." would indicate Mykhailo Kolodzinsky, were it not for the fact that the author of the above quoted OUN paper, apart from the paper written by Murovych listed two other texts whose author was Budzhak (Kolodzinsky's pseudonym).

45 М.К., Український імперіалізм, ДАЛО, f. 121, op. 3, s. 806, 11. 39-40. 
Don, Volga and the Caspian Sea to British India. The existence of this trade route would in future prevent a potential Anglo-Russian alliance against Ukraine and Japan. ${ }^{46}$ Gabrusevych and Kordiuk's use of identical symbolism, taking into account the fact that both activists were staying in the Berlin centre of the OUN, leads to the conclusion that they provided each other with inspiration. Perhaps the triangle Germany-Italy-United Ukraine, proposed by Kordiuk, appeared as a realisation of Gabrusevych's postulates operating within the "chessboard theory", according to which Ukrainians should be oriented to the neighbours of their enemies, i.e. firstly Germany and Japan, and secondly Italy and the United Kingdom. It cannot be ruled out that the inspiration was reverse. ${ }^{47}$ It is worth noting that also Gabrusevych's concepts met with criticism in the organisation. Its author was Yevhen Lakhovych, who played a similar role to Onatsky, acting as an OUN representative in Great Britain in the years 1933-1935. Referring to Gabrusevych's concept, he wrote:

First of all, I cannot take him seriously as long as he operates with symbolism, or rather with empty phraseology. Symbols such as "chessboard", "triangle in Asia", "triangle in Europe" or perhaps "square in the head" are all fit for home acrobatics. I cannot talk to foreigners in such categories. They want some specifics, they want words that would represent concrete notions and verbs that would mean a particular move.

Anyway, if Irten [Gabrusevych's pseudonym] wants to talk about the "balance of power", then why will he not say what this symbolic Ukraine-Japan-England "triangle" in Asia and Ukraine-Germany-Italy in Europe mean?

What interests do these "triangles" contain in themselves, and what forces, what interests and powers are on the other side of the equilibrium ( $^{48}$

Konovalets approached Gabrusevych's concept less critically than Lakhovych. The OUN leader argued that the theses presented by the young nationalist were generally correct, but they lacked a broader development and a corresponding scientific foundation. ${ }^{49}$ Like Onatsky's earlier negative assessment of Kordiuk's postulates, Lakhovych's criticism revealed the gulf in the mindset of the older generation of OUN activists involved in diplomatic activities, and the former foreign managers of HE OUN, who arrived in 1932-1933. At the same time, Konovalets's opinion showed that the OUN leader tried at all costs to maintain a balance in an organisation comprising members of different views, temperaments and life experiences.

Also from 1934 comes the text "Shift the war with Moskals to the whole USSR territory! - OUN on SUZ". ${ }^{50}$ This confidential document was signed "Askold". The

\footnotetext{
46 [Іван Габрусевич], Україна і Англія, ЦДАВОВ, f. 3833, ор. 3, s. 1, 1. 49.

47 Лист Габрусевича на маргінесі рапортів Є. Ляховича, ibid., ll. 54-55.

48 “Лист Є. Ляховича до Є. Коновальця від 26 квітня 1934 p.”, in: Онацький, У вічному місті $-I V$, p. 152.

49 “Лист Є. Коновальця до Є. Ляховича від 24 квітня 1934 p.”, in: ibid., p. 144.

${ }^{50} \mathrm{SUZ}$ - in OUN terminology an abbreviation of eastern Ukrainian lands (skhidnokrayinski zemli).
} 
pseudonym was used by two people in the organisation; however, as at the time Ivan Mytsyk was in a Polish prison, therefore the author was most likely the head of the ideological unit HE OUN Yaroslav Stetsko. His text differed somewhat from Kordiuk's and Gabrusevych's vision, as it was a plan for a revolutionary struggle against Russia. According to Stetsko, Ukrainians were to carry out parallel strikes in the space "from the Zbruch and the Black Sea to the Pacific and the Arctic Ocean". In the course of the revolutionary struggle, the Ukrainians were to gain i.a. Karelia, Sakhalin and Kamchatka (sic!). ${ }^{51}$ In another archival text, whose authorship can be attributed to Stetsko, we find information on the necessity of Ukraine reaching for the Bosphorus, shifting borders near Moscow, or occupying the Ural mines. ${ }^{52}$

Without a doubt, the superpower concept best-known among OUN activists was created by Mykhailo Kolodzinsky. He presented his vision in The War Doctrine of Ukrainian Nationalists, completed in 1938. The first part of this work was published in 1940 in Krakow (later also in Toronto in 1957, and in Kiev in 1999). ${ }^{53}$ The full version of the work was considered lost until 2013, when Oleksandr Zaytsev determined that it was in the Organisation of Ukrainian Nationalists Archive in Kiev, and subsequently published several texts in which he widely referred to Kolodzinsky's work. ${ }^{54}$ In it, Kolodzinsky postulated an eastern vector of Ukraine's expansion. His minimum plan was to base the eastern borders of Ukraine on the Volga and the Caspian Sea (with occupation of the Absheron Peninsula and Baku). ${ }^{55}$ At the same time, the OUN activist postulated shifting the borders of Europe "to Altai and Dzungaria", ${ }^{56}$ the Ukrainian influence extending to the republics of Turkestan, establishing Kazakhstan as a dominion, and gaining Ukrainian control over the industrial centres of Magnitogorsk and the Kuznetsk Basin. ${ }^{57}$ Compared to the plans of extensive expansion in the eastern section, the western boundaries suggested by Kolodzinsky, based on the line Tarnogrod, Bilgoraj, Szczebrzeszyn, Krasnystaw, Lubartow, Radzyn Podlaski, Lukow, Sokolow Podlaski, Drohiczyn, Bielsk Podlaski (i.e. the border in the Treaty of Brest-Litovsk

51 Аскольд [Ярослав Стецько], Перекинути війну з москалями на цілу територію СРСР - ОУН на СУЗ, АОУН, f. 1, ор. 1, s. 141, 1l. 1-5.

52 [Я. Стецько], Концепція імперіалізму, ibid., op. 2, vol. 25, 11. 68, 73.

53 G. Motyka, Wolyń ,43. Ludobójcza czystka - fakty, analogie, polityka historyczna, Kraków, 2016, p. 36.

54 О. Зайцев, Украйнський інтегральний націоналізм (1920-1930-ті роки). Нариси інтелектуальної історії, Київ, 2013, pр. 241-325; О. Зайцев, “Воєнна доктрина Михайла Колодзінського”, Україна Модерна, 2013, pp. 245-256, also as: Дефбіляда в Москві та Варшаві: 'Воєнна доктрина українських націоналістів' Михайла Колодзінського, http://uamoderna. com/event/186 (accessed: 22 January 2017); М. Колодзінський, “Націоналістичне повстання. Розділ з праці “Воєнна доктрина українських націоналістів” (публікація та коментарі Олександра Зайцева)”, Україна Модерна, 2013, рр. 256-295.

55 М. Колодзінський, Воєнна доктрина українських націоналістів, АОУН, f. 1, op. 2, s. 466, 1. 70.

56 Ibid., 1. 31.

57 Ibid., ll. 167-168. 
of 9 February 1918) can be considered simply minimalist. ${ }^{58}$ A comparison of Kolodzinsky's concept with the texts of Gabrusevych, Stetsko and Kordiuk shows that in the 1930s there was a group of younger generation activists in the OUN, who gave a clear political shape to the motto of the Decalogue of the Ukrainian Nationalist about creating a new life on the line between two worlds. These visions have even received a poetic manifesto. A young nationalist poet Oleg Olzhych, who in 1937 became the head of the culture division of the OUN, two years earlier wrote the poem To the Unknown Soldier, ending in the following words:

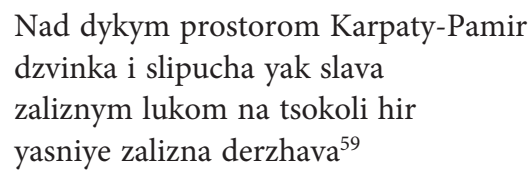

It is worth noting that older generation activists played a relatively small role in the development of OUN's geopolitical vision in the 1930s. Only Mykola Stsiborsky, in his work The agrarian question published in Paris in 1939, postulated stimulating emigration from eastern Ukraine towards the east (Caucasus, Turkestan, Caspian and Transcaspian steppes) for expansionist purposes. At the same time, Stsiborskyi cut himself off from the methods of Russian imperialism towards smaller nations, to some extent repeating Kordiuk's arguments. As he claimed:

Rapacious invasions are contradictory to the historical traditions of Ukrainian constructivism, which has always and everywhere operated through work and plough, not just sword [emphasis mine - MW]. Ukraine will take into account the existence of various nationalities on the aforementioned territories, which also organically renounce Moscow and seek to develop freely. Our policy towards these small nations will be to maintain loyalty, support and cooperation. ${ }^{60}$

At the same time, Stsiborskyi believed that smaller nations should become satellites of Ukraine. Like Kordiuk, he did not try to explain the contradiction between the free development of these nations and their vassal status towards Ukraine. Nevertheless, the OUN activist at least pointed out the limitation of direct expansionism to the Crimea and Kuban, areas he considered indispensable for Ukrainian statehood. ${ }^{61}$

Some contribution to the development of geopolitical OUN thought was brought by Ivan Mitrynga in the late 1930s. This representative of the left-wing

58 Ibid., 1. 54.

59 "Over the wild space of the Carpathian Pamir / melodious and dazzling like glory / like an iron arc on the pedestal of mountains / gleams an iron state"; О. Ольжич, "Незнаному Воякові", in: id., Вибрані твори, еd. О. Зінкевич, Київ, 2009, р. 79.

60 М. Сціборський, Земельне питання, Париж, 1939, pp. 90-91.

61 Лист М. Сціборського до Я. Стецька від 15 березня 1938, АОУН, f. 1, ор. 3, s. 3, 1. 297. 
faction in the OUN, sometimes even referred to as nationalist-Bolshevik, ${ }^{62}$ was the editor-in-chief of the magazine Het' $z$ bolshevyzmom ${ }^{63}$ at the end of the 1930s. The non-periodic publication, close to the OUN, was devoted to the various aspects of the concept of the breakup of Russia. ${ }^{64}$ This designation was suggested by the cover itself, as it showed an outline of the Soviet Union with an axe thrust in its centre. Mitrynga directly suggested the establishment of an anti-Moscow union of enslaved nations. At the same time, more than the other "young ones" he emphasised the fact that the union was to be "built on the full equality of all its members, regardless of whether the nation has 30 million or 1 million people". ${ }^{65}$ At the same time, the OUN activist opposed the Russians' involvement in an anti-Bolshevik union of the nations, believing that the forces opposing the Bolsheviks were fighting for the preservation of their nation's power to "oppress the enslaved nations even harder to further "assimilate them, although with other means than the Bolsheviks". ${ }^{66}$ Mitrynga was also cautious in his approach to the pro-German orientation popular among activists in that period. He claimed that the Soviet Union could be destroyed only from within as a result of a revolution of the enslaved nations. Ukraine, as the leader of an anti-Bolshevik union, seemed to be the key to the breakup of the USSR, and thus a valuable ally for anti-Communist countries. At the same time, Mitrynga stressed that Ukraine did not intend to pay for an alliance with territories, and that in the USSR "there are no lands without peoples". ${ }^{67}$ Mitrynga's above concepts were expanded in his works published at the beginning of World War II, and have to a limited degree influenced the political propaganda of the OUN-B.

62 Ю. Радченко, Про український 'радикальний націоналізм', 'фашизм', 'націонал-більшовизм' та культуру дискусіі, http://uamoderna.com/blogy/yurij-radchenko/liebe-bandera (accessed: 22 January 2017).

63 "Down with Bolshevism".

${ }^{64}$ The most common Ukrainian nationalist concept of the breakup of the Russian state into a number of independent entities is most often linked with the figure of Yurii Lypa (1900-1944), who in the early years of World War II published several works devoted to this problem. At the same time, we have to doubt that earlier, lesser-known concepts of the OUN affected Lypa, due to the fact that his contacts with the camp of organised nationalism were episodic (as shown by his correspondence, available in digital form on the website of the Institute of Slavic Studies of the Polish Academy of Sciences, which contains just two letters by people associated with the OUN). This activist, although he presented nationalist views, maintained much more intense contacts with the UPR environment. For many years, Lypa was also in the circle of close associates of Dmytro Dontsov and his Vistnyk. Living in Warsaw, he most likely did not even have the opportunity to read small-circulation Lviv periodicals associated with OUN, such as Het' $z$ bolshovyzmom. All the more reason to exclude the impact of Yurii Lypa's works on OUN. It only occurred during World War II; cf. Ю. Липа, Розподіл Росії, Варшава, 1941; id., Панування, труд і лад, Варшава, 1940; id., Russland und seine geopolitishen möglichkeisten, Warszawa, 1940.

65 I. Мітринга, “Большевицьке питання”, Геть з больщевизмом, 1937, по. 1, p. 2.

66 С. Орелюк [І. Мітринга], “Чи по дорозі нам з московським протибольшевицьким націоналізмом?”, Геть з большевизмом, 1937, по. 1, р. 3.

67 I. Мітринга, “За співпрацю”, Геть з больщевизмом, 1938, nr 3, p. 2. 
Geopolitical issues among OUN activists in the 1930s were of particular interest mainly to the younger generations of nationalists. More radical and uncompromising than the older generation emigrant activists, they created concepts of extreme maximalism, which could not withstand the political reality of the era. This fact was highlighted in discussions among OUN activists, reminiscent of talks between politicians and dogmatists. While the former tried to fit the idea of an independent and united Ukraine into the existing balance of power, the latter believed that it would become possible to adapt the world around to the maximalist idea. This worldview shows a clear influence of the ideas of Dmytro Dontsov, who emphasised the principles of fanaticism and dogmatism in "Nationalism". The commentator also pointed out that "imperialism is not only 'a robbery', but simultaneously the execution of public affairs in the public interest by appointed and entitled nations $[\ldots]$, [therefore] we can say that the right to self-determination is held only by imperialist nations [emphasis in the text] whose imperialism is kinetic, or potential" ${ }^{68}$ Dontsov did not translate his vision of imperialist nations into the language of practical politics. However, the activists of the young generation of OUN, to which Bohdan Kordiuk belonged, did it for him. The International Politics of Ukrainian Nationalism he penned appears as a geopolitical manifest of faith in the "Ukrainian Herrenvolk". A manifest naive and full of dogmatic attitudes, but at the same time allowing us to understand not only the ideas, but also - to a certain extent - the actions of young Ukrainian nationalists (from 1940 forming OUN-B) in the 1930s and 1940s.

The English translation of the report The International Politics of Ukrainian Nationalism is made from the Polish-language version; in square brackets are the words left out by the author, or words which are inserted to fit the text into grammatical and stylistic rules of the language.

\section{The international politics of Ukrainian nationalism ${ }^{69}$}

Under this title I understand the policy of Ukrainian nationalism, which should be followed not only where the Ukrainian people live, or in the occupied territories, but also outside the occupants' borders. This is not equivalent to the OUN's politics thus far. I will often return to this matter due to the reason that Ukrainian nationalism is at present, and certainly will also be in the future, bound to the OUN. Whether this is good or bad, is not for us to decide. The very fact of undertaking this issue, not in a referenced form but in a synthetic perspective, indicates that until now Ukrainian nationalism has had no systematic international policy, not only due to the lack of adequate resources, but also the absence of its own international

68 Д. Донцов, Націоналізм, Львів, 1926, pp. 207-208.

69 Новий [Богдан Кордюк], Міжнародня політика україгського націонпалізму, ЦДАВОВ, f. 4363 , op. 1, s. 14 , 1l. 1-6. 
concept. The foreign activities of OUN so far can present a problematic value, since the foundations of international politics have not been specified, and therefore implemented in accordance with the principles of Ukrainian nationalism. These bases and trails should therefore be defined [in accordance] with new perspectives. It is a broad topic: it is generally connected with our whole worldview and has its manifestations at every step and in the smallest move. And all practical moves are not facts in themselves, but consequences of certain assumptions. I will mention single facts from the past only as an illustration.

Similarly, our entire international policy is not a separate domain, it is only our worldview applied to international life. As in other spheres, also here [our] basic positions must also grow from the same foundations. They must be the same everywhere. If so, "The international politics of Ukrainian nationalism" will not interfere or overlap with other areas in a visible way, to the detriment of the latter and of the whole, on the contrary - it will be harmonised with the whole, both quantitatively, and qualitatively.

The First Congress established the claim that "we are a partyless organisation". This claim has been, and is now, operating in many fields. This claim cannot withstand criticism, and to a certain extent denies the political basis of nationalism, because we do not seek an agreement among different national groups to create a certain front but, by creating our own world, we oppose and fight all others. We are a group ([we] can also be called a party), but the point is that the tasks and interests of this group, and therefore ours, should be the interests and aspirations of the whole nation. All other groups defend [the interests of] only certain layers or parts of the nation. We are a movement that mobilises the whole nation, regardless of its strata and states. This must be the basis of our present activity, and the future system of the state, and before that - the system of the Organisation. Because the system of the Organisation is a glimpse of the future state system. The movement's growth in the country has long moved on from the claim of "partylessness". Abroad, this thesis often lingers in various actions and letters (e.g. the propaganda of the "pan-Ukrainian case", R[ozbudova] N[atsii] no. 11-12 [1]933).

Our foreign policy is not all-Ukrainian, but exclusively ours, nationalist, which is the only Ukrainian one. It may be, will be and must be different from other "also Ukrainian ones". We care for this "official" policy only in so far as we have to fight it, because it is led by groups essentially hostile to us, and so every practical move must be contrary [to us]. 2. There are no directions of foreign policy in other groups, with very few exceptions (e.g. UPR, hetmans ${ }^{70}$ ), which is why the practical steps of these different groups are conditional and inherently opportunistic. We are dominating life, we will shape it and build the state, therefore only our policies are reliable for us. We need to become an operator not only in the internal politics of

70 This refers to the followers of the conservative Hetman Movement with Pavlo Skoropadskyi at the helm, and the Ukrainian People's Republic in exile focused around Andriy Livytsky. 
the Ukrainian people, but also in international, global politics. One is very closely related to the other. The growth of the movement in the country gives [us] more opportunities to pursue our tasks in international politics and vice versa - great prospects and tasks in international politics provide the driving force for the movement in its foundations. Because the subject is creativity, independent and positive placing of the issue and [its] solution, and not just negative attitude towards others. At the same time, it is necessary to set a trail to a very distant purpose and consistently, independently implement it in real life. Propagating the Ukrainian name and the all-Ukrainian issue abroad is not enough. Even the all-Ukrainian issue is very differently understood. This in any case is clear, because such an issue does not exist; it is only nationalist, UNDO, ${ }^{71}$ or other. We should add that actions in foreign territory have been carried out not according to our own plan, but rarely, from time to time. If there are some successes, they must be accounted for [by] the potential weight of the Ukrainian issue, and [by] the intuitively correct approach to the issue of some single individuals. But even these people acknowledge that they have reached it by way of experiments, they made mistakes, they turned back. Why? Because it has not been clearly outlined: 1 . What are we here, abroad, supposed to do? 2. With whom? 3. For what purpose? 4. With what methods?

To answer these questions, it is necessary to return to the essential tasks of the Ukrainian nation in the world. These tasks are outlined by the past of the nation, they should be continued and expanded in the future. The outline of these tasks must be developed in our geopolitical concept.

\section{The Ukrainian geopolitical concept}

"A nation with powerful intentions is a positive, constructive, creative force. A nation will not be ingenious, original, creative without a powerful geopolitical concept". This refers above all to great nations, and even more so to the enslaved ones. So far, we did not put forward grand geopolitical concepts of this type, as [did] Vladimir the Great or Khmelnytsky. I consider the need for such a concept essential. The problem of Ukraine is not a problem of a small nation - it is a problem which, when implemented, affects the balance of Europe and completely changes the balance of power. It touches on vital interests of dozens of countries. It changes the face of the East of Europe, and creates a different balance of powers in the Far East. In a word - it is a matter of global importance. This imposes an obligation on us to be the subject, not the object in the future reconstruction of the world. And for Ukraine to obtain its rightful place and role, rather than play the role of pre-war Romania or modern satellites of France.

71 This refers to the concepts of the Ukrainian National Democratic Alliance, the most important legal Ukrainian party in the Second Polish Republic. 
The geopolitical concept is a necessary, materialised manifestation of ideology, political reason in understanding one's historical interests, and finally it is a clear, material even, image whose realisation should be strived for. It is not enough to say "we want Ukraine from the Caucasus to the San" and that is it. It is necessary to predict the balance of power, the role this new state is the play, refer to a healthy tradition, because that is what will indicate the appropriate routes. In the end, [it is necessary to] set a goal that even after building our statehood will not cease to be relevant and will still be a vital driving force. Only nations that had set themselves great goals reached their realisation, though sometimes [only] in part. Nations, who desired little, had no ambition of great aspirations, achieved nothing.

Territorially, the Ukrainian problem is the USSR, the C[zechoslovak] R[epublic], Poland and Romania, as well as the populous settled emigration. Other problems, connected to our topic are:

1. Bolshevism - its elimination or consolidation.

2. The breakup of Russia. (I separate it from the previous point, because although Bolshevism is a purely Moscow product, after its breakup, even with the help of Ukraine, it may be limited to more or less superficial changes to the regime, which does not completely change [things]).

3. Liberating the peoples of Eastern Europe and Asia, and their awakening to independent national life.

4. Stabilising the East of Europe, and to a large extent the entire Europe, and the destruction of the "steppe", which has always posed a formidable danger for Europe.

5. The opportunities for the Catholic Church in the East of Europe.

6. Economic problems.

7. The connection Baltic Sea - Black Sea.

Putting forward half-formed concepts harms us. By that I mean the LithuanianBelarusian-Galician Principality, the Galician-Volhynian state, the UNR concept of Trans-Dnieper Ukraine. All of this brings deception, countless orientations, and makes Ukraine a ball in the game of foreign powers. Finally, it is a complete misunderstanding of the Ukrainian issue. Such deception is also spreading among foreigners when talking about the Tri-Ruthenian Alliance, federalisms, Eurasiatisms $\mathrm{s}^{72}$ etc. Nevertheless, it must be admitted that other political groups have created certain, although defective, concepts which normalise relations with the neighbours, and determine the possible routes of development. We do not have it yet. There is only a phraseological statement saying that we do not cooperate with any neighbour. The lack of orientation is a platitude, because in practical

${ }^{72}$ Kordiuk refers here to the concept of a Tri-Ruthenian Alliance of Vyacheslav Lypynsky (the conservative camp), federalism of a UNR ally Józef Piłsudski; finally, the reference to "Eurasiatism" is probably a veiled criticism of the views of Vasyl Paneyko supporting a wide cooperation with the peoples of the former Russian Empire. 
terms this means their constant change, and overall a multitude of orientations. Not a mass of orientations, but one constantly repeated, regardless of momentary benefit or harm, indicates a correct perception and good understanding of the political reality. Political constellations and [space of] the rise of conflicts do not change from day to day. They are quite permanent.

All of these issues exist and we must not only take a theoretical stand about them, but also work towards solving these issues in accordance with our ideology and national interest. I will outline here our geopolitical concept in geographical meaning. Everything else should be embroidered on it like on a canvas.

More or less since the defeat at Poltava and in general since the East of Europe has been painted on the political map with one colour, an idea has taken root in the public mind that the East of Europe is a whole. No wonder - the physical map of Europe once used to show the East as one great plain, one blot from the Urals to the Carpathian Mountains. Naturally, this opinion was spread by Moskals themselves, or possibly Russians, as it was in their interest. This has also affected the development of various sciences. The history of Ukraine has been clearly pillaged, and so has the history of its culture - the rise of Ruthenia, triune Ruthenia, similarity of cultures, the Little Russian dialect. These are the consequences of such a suggestion on the part of enemies. Of course, announcing these scientific theories has only consolidated and stabilised the view of the East as a uniform whole. Individual voices of dissent have been too weak to have any impact, except for the last years before the war.

In fact, the East of Europe is in no respect a homogeneous whole. From geology to archaeology, history of culture, anthropology, ethnography, to all sorts of nationalities, it is a dappled world, in places very highly diversified. The so-called common features are artificial or artificially inoculated. For example, a similar language, which would indicate a common origin, national relationship or psychological community. Likewise, the Orthodox faith.

In national terms, it is a vast, motley land. It is a long line of nations absorbed or enslaved by the Moskals. No other state in the world is as colourful in national terms as Russia. Suffice it to say that half of the population of the USSR are "inorodtsy". ${ }^{73}$ Before the war, there were many more people of foreign origin. Poles, Lithuanians, Estonians, Finns, ${ }^{74}$ and a significant number of Ukrainians and Belarusians dropped out. When considering the psychology of Russia as a whole - it seems to be a country of great possibilities and paradoxes. I believe that if we were to analyse the psychology of Moscovia, it is a very uncomplicated country, with very limited capabilities. But if we consider the whole, it is of course

${ }^{73}$ The category of subjects in the Russian Empire law relating to most non-Slavic subjects in the Asian part of the country. In popular discourse, it was applied to all inhabitants of non-Slavic, or even non-Russian origin.

${ }^{74}$ Thus was it written. The author applies the term "Finns" to describe the representatives of all Finno-Ugric peoples, and "the Finnish" to specify the Finns. 
a conglomeration of aspirations, characters, feelings which to an investigator seem strange and diverse. Let us look at the different countries and determine certain regularities. I will not focus here on geographical and geological problems, because for us the foundation is the national aspect of the issue. I note this only to destroy the old, and unfortunately in parts still ongoing superstition about the lack of certain distinct geographical units in the East of Europe.

The Ukrainian ethnographic territory comprises lands whose core is the Ukrainian granite plate, in the south encompassed by a system of high mountains: the Carpathians, the Crimean Mountains, the Caucasus as well as the Black Sea. It is almost entirely the Black Sea basin with a great, centrally located axis - the Dnieper. Finally, Ukraine, together with Belarus, creates a bridge between the Baltic Sea and the Black Sea, which in geopolitical sense is a very precisely defined and very important whole.

The Baltic nations are, in geological terms, the "Baltic Shield", and further there is the basin of the Baltic Sea (Finland). In an even broader outline - it is the Northern Europe completely inhabited by Finns (the Finnish, Karelians, Komi, Samoyed ${ }^{75}$ ), the basin of the North Sea, ${ }^{76}$ the bridge between the Baltic Sea and the North Sea, the country of forest and tundra. In a word, a separate entity from the Urals to the Gulf of Bothnia.

Siberia is a separate country. Is a Siberian a Moskal? To a certain extent, yes. An actual Siberian is the seed of a separate nation, which will have a lot in common with Moscow, and even more to set them apart. Eastern Siberia is a vast country of the Yakuts, and in the South the Green Wedge. Along the mountain chain are the Mongolian peoples (Oirats, Buryats), which also strive for independence, and in every aspect lean towards the East and South. The independence efforts of these peoples is supported by Japan. Along the Ural Mountains there is a number of peoples, small [in terms of the] quantity, but together numerous.

What does Moscovia represent? It is the basin of the upper and middle Volga, the so-called Moscow basin in the geological sense. With these few words I wanted to sketch out the general plan of geographical and national units on the territory of the USSR, or former Russia.

The climax of Moscow imperialism has long since passed. There was a time when Russia was virtually the dictator of Europe and had no power equivalent to it. It was the period from the time after Napoleon until the war of Sevastopol. The collapse of Moscow imperialism goes hand in hand with the internal disintegration processes. The growing Polish irredenta, the actualisation of the Ukrainian issue, increased awareness of other peoples, and above all the disintegration of the ruling

${ }^{75}$ Karelians - a Finno-Ugric people living on the border of Finland and Russia (Republic of Karelia); Komi - a Finno-Ugric people today inhabiting the Komi Republic which forms part of the Russian Federation, as well as the Kola peninsula and Western Siberia; Samoyeds - a collective name of several peoples.

${ }^{76}$ Under the name North Sea the author is most likely referring to the Barents Sea. 
class and social movements. On the external front, the largest breach was 1905 and the defeat in the Far East. Inhibited expansion in this direction and the withdrawal from several positions (Port Arthur). Naturally, this withdrawal is neither permanent nor even, such is the law of nature that it runs up and down like a sinusoid. The last headlong fall was the revolution of 1917-1920. It had very clear centrifugal tendencies. Then came the response in the form of Bolshevism. In recent times, the decline has begun again. In this period, the losses are independent Poland and the Baltic States. On the domestic front [it is] the recognition of [other] nations and granting them some form of separation. It should be noted here that Soviet federalism as an idea is not the source of this or any other phenomenon, the nucleus of one or other republic, but it is the integrity of the whole range of regenerating nationalisms that forms the cause of Russian federalism. The federalism has become a remedy, which has been working in Russia for a long time. Generally speaking, this is Moscow's concession to Europe. This process indicates central weakness and a defensive, or possibly a counteroffensive. ${ }^{77}$ We should not, however, comfort ourselves with it, because also in this form a systematic and large-scale destruction of others is occurring, and how future events will turn out is going to depend in the first place on the resistance and creative force of the enslaved nations.

Ukraine is the largest part of the USSR in terms of the number [of residents], territory, and the population's awareness. It must take up the fiercest and long-term battle. Moscow is certainly not going to give up at such a low cost as it has done with Poland or the Baltic states. This is a fight to the death, or at least for a powerful, imperial position in the world. Nevertheless, due to Ukraine's tendency for growth and Moscow's tendency to turn back, Ukraine's independence is inevitable and it is a matter of time. Ukraine is now facing the task of taking the liberation of nations in its own hands. There are numerous small, self-aware nations in the Soviet Union, but none is able to lead a successful fight for independence. It is in the direct interest of Ukraine, because small nations will be used not only as a decentralisation material against Moscow, but we will also build our messianism and imperialism on that basis. In fact, the message of liberating the peoples of Eastern Europe is not new. It is currently raised and exploited by a group of Poles, and with them the UNR, but such a message cannot have moral strength in a nation, which in its own country enslaves other nations. It is therefore unrealistic for Poland, which is unable to perform these tasks, also because it is completely outside its interests. Politics must be ethical, because it is a social ethic, and therefore it does not dare to commit any deceit.

Two great, strong empires cannot exist in the East: it is either Ukraine or Moscovia. The strengthening of the steppe, the stabilising of relations is possible only on the way of eliminating the negative Moscow influence, and this is made possible by fragmenting the great "steppe" and creating a number of independent

77 Thus was it written. 
nation states. All oppressed nations believe and rightly think that genuine human progress is a function of the free development of nations. Because the liberation of full human forces which would give culture new values, can only be given by national independence.

There is one more important difference between making the case for liberating the nations by us and by others: actions should be initiated from the inside, and not be based on overfed emigration, brought up on old ideas and in old conditions. Practically: [it is necessary to] begin relations and revolutionary work with peoples on the occupied territory. In particular, all the emancipatory movements must be built on harmonious principles. It is necessary to find, or even impose, a common language in worldview matters.

In such a way the Ukrainian nationalism becomes an active factor not only in Europe, but also in Asia. With the disintegration of Russia, an important contractor drops out of the Far East. I mean the node of interests and influences in the Far East, which involves Japan, USA, indirectly England and others and, in a passive way, China. Therefore, our positions towards these contractors should already be established, as far as the knowledge of the local relations permits.

I am now turning to the issue of the West. The conviction about the rotten West suggested by the Moskals has spread and settled also among us. The West of Europe has experienced crises many times throughout its long history, and has come out [of them] victorious. The state produced after the war cannot last long. It is unhealthy and unnatural. Central Europe is torn apart without any system into a number of countries. Our principle: all peoples should be entitled to the fullness of life and growth. The post-war constellation of states has not solved this problem completely. [There are] endless examples. Our concept of Central Europe is as follows: the triangle Italy - United Germany - United Ukraine. It closes the space between each other, creating three member states built on a national basis. The national principle is assured and guaranteed to all of them. This entire complex of nations would be in the claws, but also under the care of the three states. This alliance would create a very clearly defined whole, namely as platforms: North Sea Mediterranean Sea - Baltic Sea - Black Sea. Among these nations a new worldview emerges, and they are the chorus leaders of the new world order. But only the Ukraine, like a node, will give them the ability to [fully] resolve Central Europe. Economically it is a huge space, thus designed Central Europe is a certain economic whole, which in many ways complements itself: industrial northern Germany, Mediterranean Italy and steppe-agricultural Ukraine. [There are o]pportunities for spiritual and economic expansion through Ukraine to the Middle and Far East. ${ }^{78}$

By proposing this concept, I do not so much mean whether it will be in force in this form or undergo certain changes, but I aim to collect all the existing problems which concern the interests of the Ukrainian nation, and consider them from my

78 Thus was it written. 
own point of view. By nature, we are called to the best and most prudent solution to the problem in the East of Europe. We need to be aware of this and force others to recognise this truth. The essence of our revisionism is not to move in accordance with the guidelines of others' concepts, but have others follow in the direction of ours. It is not that difficult, given the huge geographical and geopolitical position of Ukraine on the one hand, and the fact that we, the Ukrainian nationalists, are already co-creators of the new order in the world not only potentially, but also according to the measure of our activity - an activity which follows this, not other, direction. Consistently and without stopping, we need to repeat our truth both in words and in deeds, because only then we are right. Temporary, or even not temporary, alliances are good for nothing. It is $\boldsymbol{u s}$ [emphasis mine - MW] who says so, and we will prove it.

It is very dangerous to accept someone else's concepts, foreign methods. Our whole movement aims to find itself in the past, confirm itself in the present. Because only what is our own is healthy for the nation. The foreign, even if it was in fact appropriate, is harmful to another nation.

Foreign policy must be an offensive policy. This does not mean that it needs to follow the trail of enslaving other nations, following the pattern of Moscow or pre-war German imperialism. A peculiar type of offensive policy must be created. The idea of freedom, the nation's foundation without annexing and exterminating aspirations. The trail of expansion can be entirely different. Through revelling in the great mission which the Ukrainian nation has in the world, the young generation is growing up without a sense of its weakness or worthlessness, but as the Herrenvolk, aware of its purpose.

\section{Abbreviations}

CESUS - Central Union of Ukrainian Students (Tsentral'nyi Soiuz Ukrains'koho Studentstva) s. - sprava - file

f. - fond - collection

1., 11. - lyst, lysty - folio, folios

HE OUN - Homeland Executive of the Organization of Ukrainian Nationalists

op. - op. - inventory

OUN - Organization of Ukrainian Nationalists

OUN-A - Organization of Ukrainian Nationalists Abroad

OUN-B - Bandera's faction of the Organization of Ukrainian Nationalists

PUN - Leadership of the Ukrainian Nationalists (Provid Ukraïns'kykh Natsionalistiv)

SUZ - Eastern Ukrainian Lands

UNDO - Ukrainian National Democratic Alliance (Ukrayin'ske Natsional'no-Demokratichne

Obyednannia)

UNR- Ukrainian People's Republic

AOYH - Archives of the Organization of Ukrainian Nationalists in Kiev

ДАЛО - State Archives of Lviv Region

ЦДАВОВ - Central State Archives of Higher Authorities and Government of Ukraine 


\section{Bibliography}

\section{Archival materials}

Archives of the Organization of Ukrainian Nationalists in Kiev (Архів Організації Українських Націоналістів у Києві) - АОУН

- f. 1 , op. 1 , s. 141 ; op. 2 , s. 25,466 ; op. 3 , s. 3.

Central State Archives of Higher Authorities and Government of Ukraine (Центральний Державний Архів Вищих Органів Влади та Управління України) - ЦДАВОВ - f. 3833, op. 3, s. 1; f. 4363, op. 1, s. 14.

State Archives of Lviv Region (Державний Архів Львівської Області) - ДАЛО - f. 121 , op. 3, s. 806 .

\section{Secondary literature}

Lypa J., Russland und seine geopolitischen möglichkeiten, Warszawa, 1940.

Motyka G., Wolyń '43. Ludobójcza czystka - fakty, analogie, polityka historyczna, Kraków, 2016. Wysocki R., Organizacja Ukraińskich Nacjonalistów w Polsce w latach 1929-1939. Geneza, struktura, program, ideologia, Lublin, 2003.

Zięba A.A., Lobbing dla Ukrainy w Europie Międzywojennej. Ukraińskie Biuro Prasowe w Londynie i jego konkurenci polityczni (do roku 1932), Kraków, 2010.

Андрієвський Д., "Україна в світовій політиці", Розбудова націi 1928, no. 10-11.

Богуш В. [М. Кушнір], Паневропа за проектом Бряна, “Український Голос", 1930, по. 28, pp. 1-2.

Буджак М. [М. Колодзінський], Польське повстання 1863 р., Львів, 1929.

В’ятрович В., Друга польсько-українська війна 1942-1947, Київ, 2012.

Гайвас Я., Воля ціни не має, Торонто, 1971.

Документи і матеріали з історії Організації Українських Націоналістів, vol. 1: 1927-1930, up. Ю. Черченко, О. Кучерук, Київ, 2005.

Документи і матеріали з історії Організації Українських Націоналістів, vol. 2, part 2, up. Ю. Черченко, Київ, 2007.

Документи і матеріали з історії Організації Українських Націоналістів, vol. 2, part 1, up. Ю. Черченко, Київ, 2010.

Донцов Д., Націоналізм, Львів, 1926.

Євген Коновалець та його доба, Мюнхен, 1974.

Зайцев О., “Воєнна доктрина Михайла Колодзінського”, Україна Модерна, 2013, pp. 245256.

Зайцев О., Дебіляда в Москві та Вармаві: “Воєнна доктрина українських націоналістів" Михайла Колодзінського, http://uamoderna.com/event/186 (accessed: 22 January 2017).

Зайцев О., Український інтеsральний націоналізм (1920-1930-ті роки). Нариси інтелектуальної історії, Киїів, 2013.

Книш 3., При джерелах українського організованого націоналізму, Торонто, 1970.

Колодзінський М., "Націоналістичне повстання. Розділ з праці "Воєнна доктрина українських націоналістів" (публікація та коментарі Олександра Зайцева)”, Україна Модерна", 2013, pр. 256-295.

Коньрес Українських Націоналістів 1929 р.: Документи і матеріали, еd. В. Муравський, Львів, 2006. 
Ленкавський С., “Філософічні підстави 'Націоналізму’ Донцова”, Розбудова нації, 1928, no. $7-8$, pp. $272-275$.

Липа Ю., Панування, труд і лад, Варшава, 1940.

Липа Ю., Розподіл Росіі, Варшава, 1941.

Мірчук П., Нарис історії Оргвнізації Українських Націоналістів, Мюнхен-Лондон-Нью Йорк, 1968.

Мітринга І., “Большевицьке питання”, Геть з большевизмом, 1937, по. 1, р. 2.

Мітринга І., “За співпрацю”, Геть з большевизмом, 1938, по. 3, pp. 1-2.

Ольжич О., Вибрані твори, uр. О. Зінкевич, Київ, 2009.

Онацький Є., “Паневропа чи антиевропа”, Український Голос, 1930, no. 20-22.

Онацький Є., У вічному місті IV. Записьки українського журналіста 1934 рік, Торонто, 1989.

Орелюк С. [І. Мітринґа], “Чи по дорозі нам з московським протибольшевицьким націоналізмом?”, Геть з большевизмом, 1937, по. 1, р. 3.

Радченко Ю., Про украӥнський "радикальний націоналізм”, “фашизм”, “націоналбільшовизм" та культуру дискусії, http://uamoderna.com/blogy/yurij-radchenko/liebe-bandera (accessed: 22 January 2017).

Ребет Л., Світла і тіні ОУН, Мюнхен, 1964.

Сціборський М., Земельне питання, Париж, 1939.

Marek Wojnar, MA in history, assistant at the Department of Central and Eastern Europe, Institute of Political Studies, Polish Academy of Sciences; in 2012-2014 involved in the project "Histories and Memories of Empires in Eastern Europe - Comparative Studies" of the Foundation for Polish Science. His research interests include political thought and historical memory in Eastern Europe with particular emphasis on Ukraine (marek.wojnar@gmail.com). 